\title{
CALCIUM AND PHOSPHORUS METABOLISM IN RHEUMATOID ARTHRITIS AND DEGENERATIVE JOINT DISEASE 1, 2
}

\author{
By MARIAN W. ROPES, ELSIE C. ROSSMEISL, AND WALTER BAUER \\ (From the Medical Clinic of the Massachusetts General Hospital, the Department of Medicine, \\ Harvard Medical School, and the Massachusetts Department of Public \\ Health, Boston)
}

(Received for publication November 10, 1942)

The occurrence of marked decalcification in patients with rhematoid arthritis, and of marginal lipping or osteophyte formation in individuals with degenerative joint disease, ${ }^{3}$ suggested that an alteration of calcium and phosphorus metabolism might be a primary feature of these diseases. The present study was undertaken to determine whether any such metabolic abnormality occurs in either condition.

The calcium and phosphorus metabolism of these two types of joint disease has not been adequately studied, most workers having determined only the serum calcium and phosphorus levels. In both diseases, these values have been essentially normal ( 1 to 8$)$. The blood phosphatase was normal in 10 patients with rheumatoid arthritis and 11 patients with degenerative joint disease, studied by Race (7).

Essentially normal blood values of calcium and phosphorus, however, do not rule out abnormalities of calcium and phosphorus metabolism, for they do not give any information as to the intake, output, and resulting metabolic balance of these substances. Quantitative study of the calcium and phosphorus balance is possible with the use of a neutral, constant diet, adequate in all respects except calcium. Such a low calcium diet makes possible a study of the endogenous calcium metabolism and practically eliminates the factor of variations in the amount of calcium absorbed. Normal individuals between the ages of 19 and 60 have been studied on a low calcium, slightly

1 This is publication No. 72 of the Robert W. Lovett Memorial for the study of crippling disease, Harvard Medical School, Boston.

2 The arthritis studies in this clinic are made possible by a grant from the Commonwealth Fund, New York City.

8 The synonyms commonly used are hypertrophic arthritis, osteoarthritis, degenerative arthritis, and arthritis deformans. acid diet, previously (8), and can be used as controls.

\section{METHODS}

The calcium, phosphorus, and nitrogen metabolism has been studied in 9 patients with rheumatoid arthritis and 3 patients with degenerative joint disease. All of the patients were studied on the Metabolism Ward of the Massachusetts General Hospital (9). Each patient was kept on a constant fluid intake and on a diet which was accurately weighed, constant, and adequate in calories and vitamins. The mineral content was adequate except for the low calcium intake. In all cases, the diets had an essentially neutral ash. The patients were on the diet for 7 to 12 days before the experiments were started. The urine and stools were carefully collected in 3-day periods, using carmine to mark the fecal periods. All of the patients were kept essentially in nitrogen balance in order to eliminate the effect of tissue destruction on the acid-base metabolism.

Calcium was determined by the method of Fiske and Logan (10), phosphorus by that of Fiske and Subbarow (11), nitrogen by a modification of the macro-Kjeldahl method, and phosphatase by the method of Bodansky (12).

The serum calcium and phosphorus were determined in all of the patients whose metabolism was studied and on 64 other cases of rheumatoid arthritis and 3 others with degenerative joint disease.

\section{RESULTS}

The values for serum calcium and phosphorus were essentially normal in all cases. The range of variation in calcium in the rheumatoid patients was from 8.0 to $11.6 \mathrm{mgm}$. per $100 \mathrm{cc}$., with a median at $10.0 \mathrm{mgm}$. (Figure 1 ). Two of the 4 sera with calcium contents below $9.0 \mathrm{mgm}$. per $100 \mathrm{cc}$. had protein concentrations of only 4.3 and 6.1 grams per $100 \mathrm{cc}$., and a third contained only 2.5 grams of albumin. The concentrations of ionized calcium in these 3 sera presumably were normal. The values for serum phosphorus in the rheumatoid group ranged between 2.6 and 5.5 mgm. per $100 \mathrm{cc}$., with a median at $3.8 \mathrm{mgm}$. In the patients with degenerative joint disease, the 

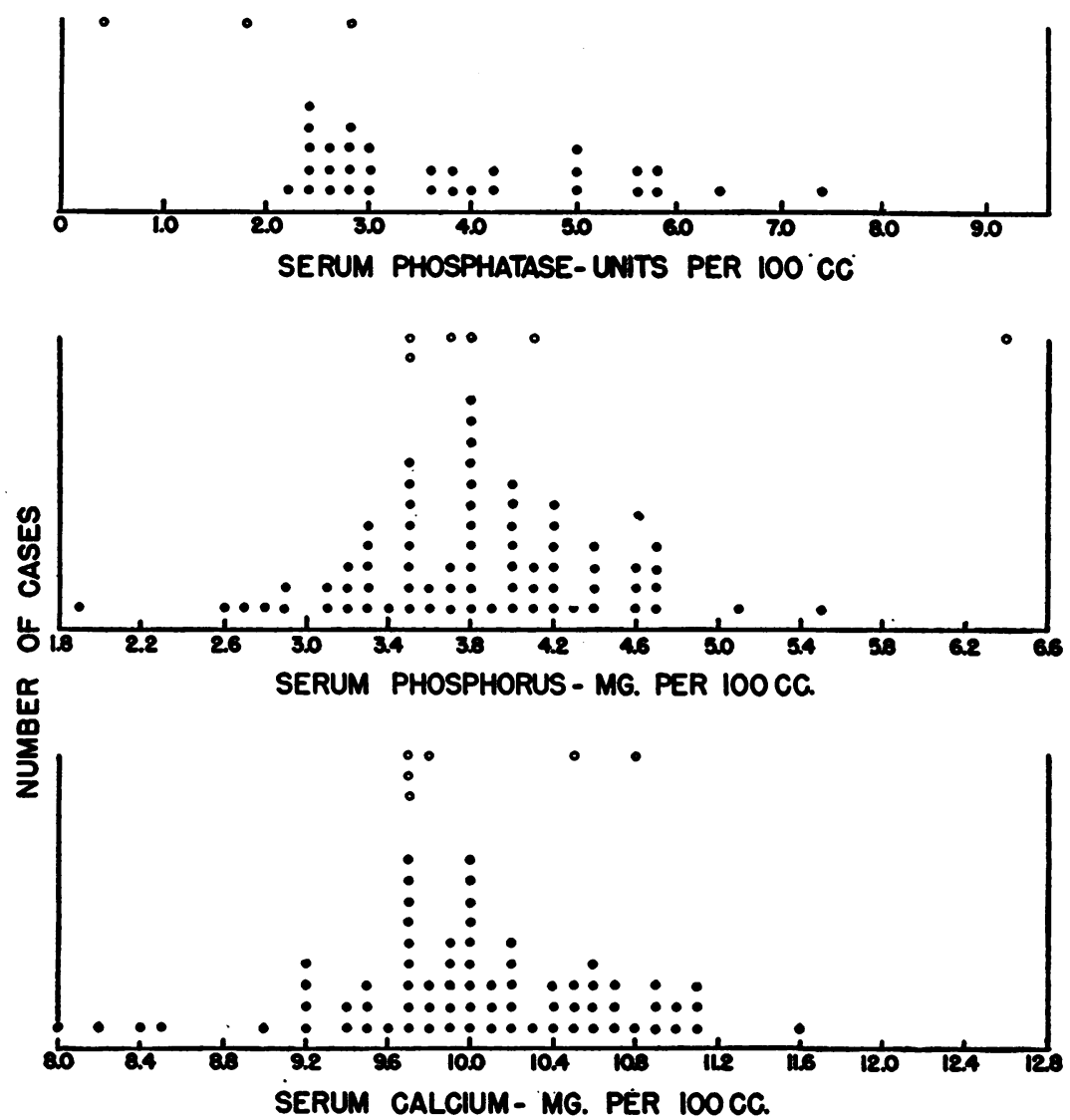

Fig. 1. Serum Calcium, Phosphorus, and Phosphatase Concentrations

The open circles represent cases of degenerative joint disease, whereas the solid circles indicate cases of rheumatoid arthritis.

serum calcium varied from 9.7 to $10.8 \mathrm{mgm}$. per 100 cc., with a median at $9.8 \mathrm{mgm}$., while the phosphorus showed a range of variation from 3.5 to $6.4 \mathrm{mgm}$. per $100 \mathrm{cc}$., with a median at $3.7 \mathrm{mgm}$.

Serum phosphatase, determined in 32 rheumatoid patients and 3 cases of degenerative joint disease, was found to be normal in all except 2 rheumatoid cases which showed values of 6.4 and 7.3 units per $100 \mathrm{cc}$. X-rays of the tibiae in the patient whose phosphatase was 7.3 units showed changes consistent with Paget's disease. The value of 6.4 units was obtained in a boy of 12 . The normal phosphatase in rheumatoid arthritis indicates the absence of any marked osteoblastic activity in this disease in contrast to conditions in which decalcification is accompanied by marked osteoblastic activity in an attempt at rapid repair.

Of more significance than the blood levels, in determining the calcium and phosphorus exchange in the bones, are the direction of flow and rate of metabolism of these substances. In hyperthyroidism, for instance, there is an extreme loss of calcium and phosphorus even though the serum levels are within normal limits (13).

The calcium and phosphorus excretion in the 9 rheumatoid patients of this series is summarized in Table I. Although the average negative calcium balance of this group on a low calcium diet ( $0.51 \mathrm{gram})$ is only slightly above that of the control series ( 0.46 gram), the difference between the two groups is apparent when one considers the urinary excretion alone. The average urinary calcium excretion for the rheumatoid group is 0.32 gram per 3-day period, in contrast to the normal of 0.19 gram. The values for individual periods in any one patient are fairly constant, but there is marked variation from patient to patient in the calcium excretion and calcium balance 
(Figure 2). Consideration of the weights of the patients, by calculating the calcium excretion per kilogram, does not lessen the variations between individual patients and changes only slightly the relation between the average excretion of the rheumatoid group (15.1 $\mathrm{mgm}$. per $\mathrm{kgm}$.) and that of the controls (12.7 mgm. per kgm.). However, comparison of the distribution of values for the individual rheumatoid patients with that for the control series (Figure 3) shows a slight but definite tendency for the calcium excretion to be higher in the rheumatoid group. The excretion in 7 of the 9 rheumatoid patients ( 78 per cent) was above the average normal of $12.7 \mathrm{mgm}$. per $\mathrm{kgm}$., while it was above the average in only 5 of 18 controls (28 per cent) $(8,14,15)$.

It is of importance to determine whether the deviation from the control group and the varia-

TABLE I

CALCIUM EXCRETION

Rheumatoid Arthritis

\begin{tabular}{|c|c|c|c|c|c|}
\hline Case & Urine & Feces & Intake & Balance & Excretion \\
\hline & \multicolumn{4}{|c|}{ grams per S-day period } & $\begin{array}{l}\text { mgm. per } \\
\text { kgm. per s. } \\
\text { day period }\end{array}$ \\
\hline 1 & 0.34 & 0.24 & 0.24 & -0.34 & 11.9 \\
\hline 2 & $\begin{array}{l}0.14 \\
0.26\end{array}$ & $\begin{array}{l}0.40 \\
2.66\end{array}$ & $\begin{array}{l}0.25 \\
3.36\end{array}$ & $\begin{array}{l}-0.30 \\
+0.43\end{array}$ & 8.3 \\
\hline 3 & 0.30 & 0.28 & 0.33 & -0.25 & 14.6 \\
\hline 4 & $\begin{array}{l}0.41 \\
0.58\end{array}$ & $\begin{array}{l}0.35 \\
1.81\end{array}$ & $\begin{array}{l}0.23 \\
3.14\end{array}$ & $\begin{array}{l}-0.53 \\
+0.76\end{array}$ & 14.2 \\
\hline 5 & $\begin{array}{l}0.48 \\
0.74\end{array}$ & $\begin{array}{l}0.34 \\
1.97\end{array}$ & $\begin{array}{l}0.20 \\
2.52\end{array}$ & $\begin{array}{l}-0.61 \\
-0.19\end{array}$ & 15.8 \\
\hline 6 & $\begin{array}{l}0.59 \\
0.77\end{array}$ & $\begin{array}{l}0.63 \\
2.17\end{array}$ & $\begin{array}{l}0.30 \\
3.24\end{array}$ & $\begin{array}{l}-0.92 \\
+0.30\end{array}$ & 19.2 \\
\hline 7 & 0.10 & 0.63 & 0.28 & -0.45 & 14.8 \\
\hline 8 & $\begin{array}{l}0.02 \\
0.02\end{array}$ & $\begin{array}{l}0.72 \\
2.19\end{array}$ & $\begin{array}{l}0.28 \\
2.42\end{array}$ & $\begin{array}{l}-0.46 \\
+0.24\end{array}$ & 17.7 \\
\hline 9 & 0.53 & 0.46 & 0.30 & -0.69 & 19.6 \\
\hline
\end{tabular}

Degenerative Joint Disease

\begin{tabular}{c|c|c|c|c|c}
\hline 10 & 0.20 & 0.30 & 0.28 & -0.23 & 7.3 \\
& 0.42 & 0.33 & 0.31 & $-0.43^{*}$ & \\
11 & 0.17 & 0.38 & 0.31 & -0.24 & 6.7 \\
& 0.84 & 0.31 & 0.31 & $-0.85^{*}$ & \\
12 & 0.08 & 0.75 & 0.23 & -0.59 & 10.1 \\
& 0.32 & 0.29 & 0.14 & $-0.48^{*}$ & \\
\hline
\end{tabular}

* During period of ammonium chloride administration.

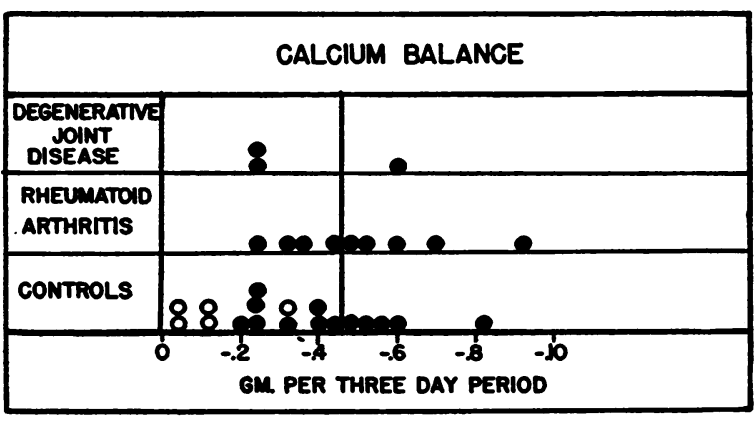

Fig. 2. Calctum Balance

The heavy line represents the average balance in the control cases of the present series $(-0.46$ gram per 3day period). The open circles indicate controls from other series $(14,15)$.

tions between individual patients can be ascribed to any of the factors known to influence the rate of calcium metabolism (age, concentration of phosphorus and of cations other than calcium in the diet, and the ratio of acid- and base-forming components in the diet). Eight of the patients were between the ages of 20 and 57, in which range it is probable that there is no alteration in the rate of calcium metabolism that can be ascribed to age. An increased excretion of calcium can occur at the time of and after the menopause (16), but the present series showed equal distribution of low and high calcium excretions in cases before, during, and after the menopause. The variations cannot be explained by diet since in all cases the diets were essentially the same. No apparent relationship was found between the calcium excretion and the duration of the disease.

The effect of inactivity on calcium metabolism has not been thoroughly studied. The phenomenon of atrophy of bone from disuse is well known, but that a detectable abnormality in calcium excretion, when measured on low calcium diet, is always associated has not been shown. The few available studies of the calcium excretion of patients at complete rest in bed and on a low calcium intake vary markedly. In one case (a patient with marked structural scoliosis studied by Farquharson, Salter, Tibbetts, and Aub (14)), the calcium excretion on low calcium diet was slightly increased during a period of complete rest in a plaster shell but remained within normal limits. The excretion rose from 10.0 to $12.7 \mathrm{mgm}$. per $\mathrm{kgm}$. with a corresponding increase in the nega- 


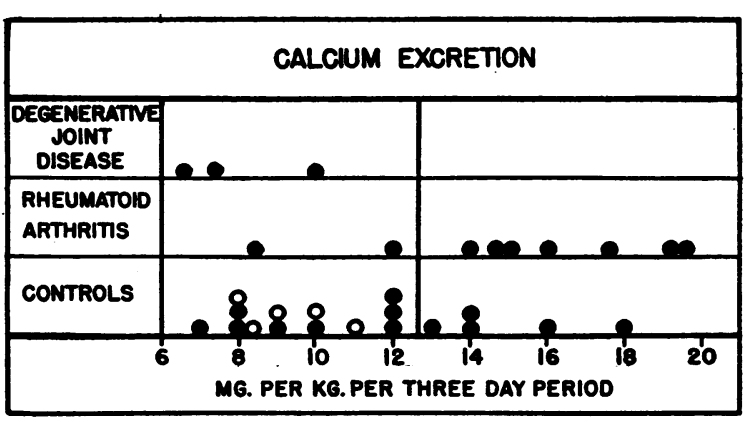

Fig. 3. Calcium Excretion

The heavy line represents the average excretion in the control cases of the present series $(12.7 \mathrm{mgm}$. per $\mathrm{kgm}$. per 3-day period). The open circles indicate controls from other series $(14,15)$.

tive calcium balance from 0.03 to 0.11 gram per 3 day period. In similar studies, carried out in this laboratory on an essentially normal 14-year old boy, the negative calcium balance increased from the abnormally low value of 0.03 gram during the control period to the high value of 0.98 gram during a period of immobilization in traction, 3 weeks after a shelf operation for a hip deformity (15). The variation between these 2 cases indicates that the effect of inactivity is by no means constant. Evidence that calcium excretion is not necessarily increased by limitation of activity is provided by 2 of the cases of degenerative joint disease in the present series who were at absolute bed rest before and during the periods of study. In both cases, the calcium excretion was well below the average normal, being 6.7 .and $10.1 \mathrm{mgm}$. per kgm. per 3-day period. Furthermore, the rheumatoid patient who had the highest calcium excretion was not confined to bed entirely but was up 2 hours a day and walked for short periods at these times. Only 2 of the 7 rheumatoid patients with abnormally high calcium excretions were at absolute bed rest. Therefore, the increased calcium excretion in the rheumatoid patients cannot be ascribed entirely to inactivity.

A comparison of the amount of decalcification, as shown by radiologic examination, with the calcium metabolism reveals an interesting correlation. Roentgenograms in 6 of the cases showed moderate or marked atrophy in contrast to slight or no atrophy in the other 3 cases. The average negative calcium balances in the 2 groups were 0.61 and 0.30 gram, respectively. In terms of cal- cium excretion per kilogram of weight, to compare with the average normal of 12.7 , the former group excreted 16.9, the latter $11.6 \mathrm{mgm}$. per $\mathrm{kgm}$.

The results of the metabolic studies suggest a slight though definite increase in calcium excretion in rheumatoid arthritis-an increase which cannot be explained by any of the factors known to influence calcium metabolism. In all cases except one, the increase was in the urinary excretion, the fecal excretions being in general below the average for the controls, in contrast to the results obtained by Robbins (17). The significance of abnormal urinary excretion of calcium is not known, but it presumably represents an increased rate of calcium metabolism. It is noteworthy that the highest excretions occurred in the patients whose $x$-rays showed the greatest amount of bony atrophy, while the only excretions below normal were in 2 patients whose $x$-rays showed only slight or no bony atrophy.

The phosphorus metabolism in the 9 cases of rheumatoid arthritis was found to be essentially normal. The theoretical phosphorus balances calculated from the phosphorus equivalents of the calcium and nitrogen excretions (13) are in close agreement with determined phosphorus balances in all cases.

The calcium, phosphorus, and nitrogen metabolism on a neutral, high calcium diet was studied in 5 of the patients with rheumatoid arthritis. The calcium balance became positive in the 3 cases who received over 3.0 grams of calcium per 3-day period and in 1 case receiving only 2.4 grams. The fact that the calcium balances are positive indicates that no marked loss of calcium occurs, but it is conceivable that there is a slight loss which is not detectable because it is within the limits of error of such metabolic studies.

The relatively slight abnormality of the calcium and phosphorus excretion in these 9 cases of rheumatoid arthritis, and the normal serum levels of calcium and phosphorus in 73 patients with rheumatoid arthritis, provide strong evidence against the hypothesis, proposed by some earlier workers (18 to 21), that rheumatoid arthritis is due to hyperparathyroidism. It has been pointed out previously that the clinical findings in rheumatoid arthritis do not support such an hypothesis (22 to 24). 
The calcium metabolism in the 3 patients with degenerative joint disease (Table I) was essentially normal, but there was a definite tendency for the excretion to be slightly lower than that found in the normal and rheumatoid groups. The average excretion for the degenerative group was $8.0 \mathrm{mgm}$. per $\mathrm{kgm}$. in contrast to the normal of $12.7 \mathrm{mgm}$. per $\mathrm{kgm}$. The distribution chart of the excretion in individual patients showed all 3 patients below the average normal, in contrast to only 22 per cent ( 2 cases) of the rheumatoid group and 72 per cent (13 cases) of the normals (Figure 3). The urinary excretion in the 3 cases was normal ( $0.15 \mathrm{gram})$. The low excretions are especially significant in view of the fact that 2 of the 3 patients were at absolute bed rest before and during the periods of study. The phosphorus excretion in the degenerative joint disease cases was normal, the theoretical phosphorus balances agreeing closely with the determined balances.

The response to ammonium chloride in the 3 patients with degenerative joint disease was normal. The urinary calcium excretion rose to levels comparable to those found by Farquharson, Salter, Tibbetts, and Aub (14) (ranging from 200 to 500 per cent of the control values of urinary excretion). The fecal calcium excretion was unchanged in the ammonium chloride periods, as was found in the cases studied by Farquharson et al.

\section{CONCLUSION}

The only conclusion one is justified in drawing from the above results is that the calcium and phosphorus metabolism is grossly normal in patients with rheumatoid arthritis and degenerative joint disease. However, detailed analysis, as outlined above, indicates a slight tendency toward an increased rate of calcium metabolism and increased calcium excretion in patients with rheumatoid arthritis, and a decreased calcium excretion in individuals with degenerative joint disease. The magnitude of the increased loss and retention, respectively, is small and may not be of importance. However, the variations from normal cannot be explained by any of the factors known to influence calcium metabolism, and although slight, may be sufficiently great to be of significance over a long period of time.

\section{BIBLIOGRAPHY}

1. Pemberton, R., and Foster, G. L., Studies on arthritis in the army based on 400 cases. III. Studies on the nitrogen, urea, carbon dioxid combining power, calcium, total fat and cholesterol of the fasting blood, renal function, blood sugar and sugar tolerance. Arch. Int. Med., 1920, 25, 243.

2. Nachlas, I. W., Studies on the blood calcium and phosphorus in arthritis. J. Bone and Joint Surg., 1927, 9, 37.

3. Hartung, E. F., Greene, C. H., and Bruger, M., Calcium and cholesterol metabolism in arthritis. Proc. American Assn. for the Study and Control of Rheum. Dis., 1934, p. 14.

4. Gray, J. W., Bernhard, W. G., and Gowen, C. H., The clinical pathology of rheumatoid arthritis. Am. J. Clin. Path., 1935, 5, 489.

5. Lahey, F. H., and Haggart, G. E., Hyperparathyroidism; clinical diagnosis and operative technique of parathyroidectomy. Surg., Gynec. and Obst., 1935, 60, 1033.

6. Race, J., Biochemical investigations in chronic rheumatic diseases. Reports on Chronic Rheum. Dis., H. K. Lewis \& Co., Ltd., London, 1935, Number 1, p. 55.

7. Race, J., The phosphatase test in the arthritides and osteitides. Arch. M. Hydrol., 1932, 10, 6.

8. Bauer, W., Albright, F., and Aub, J. C., Studies of calcium and phosphorus metabolism. II. The calcium excretion of normal individuals on a low calcium diet, also data on a case of pregnancy. J. Clin. Invest., 1929, 7, 75.

9. Bauer, W., and Aub, J. C., Studies of inorganic salt metabolism. I. The ward routine and methods. J. Am. Dietet. A., 1927, 3, 106.

10. Fiske, C. H., and Logan, M. A., Determination of Calcium. In Folin's Laboratory Manual of Biological Chemistry. Appleton-Century Co., New York, 1934, 5th ed., p. 349.

11. Fiske, C. H., and Subbarow, Y., The colorimetric determination of phosphorus. J. Biol. Chem., 1925, 66, 375.

12. Bodansky, A., Phosphatase studies. II. Determination of serum phosphatase. Factors influencing the accuracy of the determination. J. Biol. Chem., 1933, $101,93$.

13. Aub, J. C., Bauer, W., Heath, C., and Ropes, M., Studies of calcium and phosphorus metabolism. III. The effects of the thyroid hormone and thyroid disease. J. Clin. Invest., 1929, 7, 97.

14. Farquharson, R. F., Salter, W. T., Tibbetts, D. M., and Aub, J. C., Studies of calcium and phosphorus metabolism. XII. The effect of the ingestion of acid-producing substances. J. Clin. Invest., 1931, 10, 221.

15. Unpublished data.

16. Albright, F., Personal communication.

17. Robbins, C., Personal communication. 
18. Oppel, V. A., Parathyroidectomy for ankylosing polyarthritis. Ann. Surg., 1929, 90, 978.

19. Taddei, D., Di un caso di poliartrite anchilosante giovanile trattato con emiparatiroidectomia. $\mathrm{Ri}$ forma med., 1929, 45, 519.

20. Leriche, R., and Jung, A., Position actuelle du problème de la polyarthrite ankylosante et de son traitement par les opérations parathyroidiennes. Lyon chir., 1931, 28, 408.
21. Simon, R., Parathyroides et rhumatisme chronique déformant. Gaz. d. Hôp., 1931, 104, 1947.

22. Bauer, W., Hyperparathyroidism: a distinct disease entity. J. Bone and Joint Surg., 1933, 15, 135.

23. Turpin, $R$., Rhumatisme chronique et parathyroides. Progrès méd., 1939, 67, 1297.

24. d'Afflitto, V., La legatura delle arterie tiroidee inferiori nelle artriti anchilosanti (contributo clinico). Riforma med., 1940, 56, 535. 